\title{
Experimental and computational analysis of mouse sleep-wake dynamics
}

\author{
Farid Yaghouby ${ }^{1 *}$, Ting Zhang ${ }^{2}$, Martin Striz ${ }^{2}$, James Crawford ${ }^{1}$, Kevin Donohue ${ }^{3}$, Bruce O'Hara ${ }^{2}$, \\ Sridhar Sunderam ${ }^{1}$ \\ From 11th Annual UT-ORNL-KBRIN Bioinformatics Summit 2012 \\ Louisville, KY, USA. 30 March - 1 April 2012
}

\section{Background}

Genetic and behavioral screening of mice play important roles in sleep research, but the need for invasive electrophysiological (EEG/EMG) measurements for determination of sleep-wake and behavioral state limits the scope and rate of experimentation.

\section{Materials and methods}

In this study we explore the utility of a noninvasive method based on the signal from a piezoelectric sensor on the cage floor for scoring sleep-wake behavior in mice. It was previously demonstrated that the piezo signal can accurately discriminate sleep from wake activity; however, this was verified mostly by visual observation. Here we perform a more objective validation by correlating piezo measurements with EMG activity, which is dramatically suppressed during sleep. Furthermore, the piezo sensor is sensitive to respiration-related thoracic movements. Since breathing is relatively irregular in REM sleep compared to non-REM, we extract piezo features that reflect breathing regularity to try to distinguish between these sleep states.

\section{Results}

We validate our methods against simultaneous video/ EEG/EMG measurement, which constitute the gold standard for scoring sleep. But rather than rely on subjective visual scoring to determine state, we use an unsupervised probabilistic model, the hidden Markov model (HMM), to automatically partition time series of extracted EEG/EMG features into REM, non-REM and wake states. A similar HMM, estimated exclusively from piezo features of instantaneous energy and breathing regularity, displayed

\footnotetext{
* Correspondence: f.yaghouby@uky.edu

${ }^{1}$ Center for Biomedical Engineering, University of Kentucky, Lexington, KY 40506, USA

Full list of author information is available at the end of the article
}

dynamical stages with a similarity to REM/non-REM sleep, transient arousal, and wakefulness. These preliminary results suggest that a combination of piezoelectric measurements and computational modeling could yield a novel noninvasive method for analysis of sleep and sleeprelated disorders.

\section{Author details \\ ${ }^{1}$ Center for Biomedical Engineering, University of Kentucky, Lexington, KY 40506, USA. ${ }^{2}$ Department of Biology, University of Kentucky, Lexington, KY 40506, USA. ${ }^{3}$ Department of Electrical and Computer Engineering, University of Kentucky, Lexington, KY 40506, USA.}

Published: 31 July 2012

doi:10.1186/1471-2105-13-S12-A21

Cite this article as: Yaghouby et al.: Experimental and computational analysis of mouse sleep-wake dynamics. BMC Bioinformatics 201213 (Suppl 12):A21.
Submit your next manuscript to BioMed Central and take full advantage of:

- Convenient online submission

- Thorough peer review

- No space constraints or color figure charges

- Immediate publication on acceptance

- Inclusion in PubMed, CAS, Scopus and Google Scholar

- Research which is freely available for redistribution

Submit your manuscript at www.biomedcentral.com/submit
C Biomed Central
C Biomed Central

C 2012 Yaghouby et al; licensee BioMed Central Ltd. This is an Open Access article distributed under the terms of the Creative Commons Attribution License (http://creativecommons.org/licenses/by/2.0), which permits unrestricted use, distribution, and reproduction in any medium, provided the original work is properly cited. 